\title{
Correction to: The Socialist Ideas of the British Left's Alternative Economic Strategy
}

\section{Correction to:}

B. Tufekci, The Socialist Ideas of the British Left's Alternative Economic Strategy, https://doi.org/10.1007/978-3-030-34998-1

The original version of the book was inadvertently published with an incorrect affiliation of the book author "Baris Tufekci". The corrections to this affiliation have been updated.

The updated version of the book can be found at https://doi.org/10.1007/978-3-030-34998-1

(C) The Author(s) 2020

B. Tufekci, The Socialist Ideas of the British

Left's Alternative Economic Strategy, https://doi.org/10.1007/978-3-030-34998-1_8 